\title{
RETRACTED ARTICLE: MKK7 and MKK9 (mitogen-activated protein kinase kinase) are to be involved in leaf emergence during de-etiolation
}

\author{
Sujan S. Bimal ${ }^{1} \cdot$ Papdi Csaba $^{1} \cdot$ Laszlo Bogre $^{1}$
}

Received: 28 June 2016/Accepted: 24 May 2017/Published online: 23 December 2017

(C) Indian Society for Plant Physiology 2017

This article [1] has been retracted at the request of the authors as some were not aware of the submission and do not agree with its findings. All authors agree to this retraction. 1. Bimal, S.S., Csaba, P. \& Bogre, L. Ind J Plant Physiol. (2017). https://doi.org/10.1007/s40502-017-03201.

Electronic supplementary material The online version of this article (https://doi.org/10.1007/s40502-017-0320-1) contains supplementary material, which is available to authorized users.

Sujan S. Bimal

Sujan.Bimal.2010@live.rhul.ac.uk

1 Plant Molecular Sciences, School of Biological Sciences, Royal Holloway University of London, Egham,

Surrey TW20 0EX, UK 